\title{
ANALISIS PROFITABILITAS USAHA AGROINDUSTRI KECAP CAP JAGO \\ (Studi Kasus pada Perusahaan Kecap Cap Jago di Desa Cibenda Kecamatan Parigi Kabupaten Pangandaran)
}

\author{
PROFABILITY OF SOY SAUCE CAP JAGO AGROINDUSTRY BUSINESS \\ (case study in a soy sauce company in the villageof Cibenda, Parigi District, \\ Pangandaran Regency)
}

\author{
INDRI PUSPA DEWI ${ }^{1}$ *, DINI ROCHDIANI ${ }^{2}$, SUDRAJAT ${ }^{1}$ \\ ${ }^{1}$ Fakultas Pertanian Universitas Galuh \\ ${ }^{2}$ Fakultas Pertanian Universitas Padjajaran \\ *E-mail : puspadewiindri@gmail.com
}

\begin{abstract}
ABSTRAK
Salah satu subsistem agribisnis adalah agroindustri kecap. Kecap merupakan hasil olahan dari gula merah dan kedelai yang banyak digunakan sebagai penyedap makanan ataupun bumbu dapur berupa cairan berwarna merah kecoklatan rasanya ada yang manis dan ada yang asin. Penelitian ini bertujuan untuk mengetahui : 1) Besarnya biaya, penerimaan, pendapatan, dan $\mathrm{R} / \mathrm{C}$ pada agroindustri kecap dalam satu kali proses produksi. 2) Besarnya profitabilitas pada agroindustri kecap dalam satu kali proses produksi. Penelitian ini dilaksanakan di Desa Cibenda Kecamatan Parigi Kabupaten Pangandaran. Jenis penelitian yang digunakan adalah studi kasus pada agroindustri kecap di Desa Cibenda Kecamatan Parigi Kabupaten Pangandaran. Sampel diambil dengan cara purposive sampling pada agroindustri kecap dengan pertimbangan usaha tersebut merupakan usaha kecap paling lama berdiri di Desa Cibenda Kecamatan Parigi Kabupaten Pangandaran. Data yang digunakan pada penelitian ini bersumber dari data primer dan data sekunder. Data primer berasal dari wawancara langsung dengan pemilik agroindustri kecap, dimana wawancara disertai dengan daftar pertanyaan berupa kuisioner yang telah dipersiapkan terlebih dahulu. Data sekunder adalah data yang berasal dari instansi terkait. Hasil penelitian menunjukkan : 1. Biaya yang dikeluarkan oleh agroindustri kecap cap jago dalam satu kali proses produksi adalah sebesar Rp 17.024.435,44, 2. Penerimaan sebesar Rp 21.600.000, pendapatan yang diperoleh perusahaan sebesar Rp 4.575.564,56, 3. Profitabilitas yang diperoleh agroindustri kecap cap jago adalah sebesar 21,18 \% dalam satu kali proses produksi.
\end{abstract}

Kata Kunci : Agroindustri, Kecap, Profitabilitas.

\begin{abstract}
On of the agrobusiness subsystem is soy sauce ago-industry. Soy sauce is the result of processed from brown sugar and soybean which is widely useda as a spice in the kitchen or food flavoring in the form of brownish red liquid that tastes sweet or salty. The study aims to find out: 1) The amount of revenue, income, and $R / C$ costs in soy sauce agroindustry in one production process. 2) The amount of profitablity in soy sauce agroindustry in one production process. This research was conducted in the Village of Cibenda, Pargi sub-district, Pangandaran District. The type of reseach used sa case study on soy sauce agroindustry in the Village of Cibenda, Parigi sub-District, Pangandaran District. The sampel was take by purposive smpling in the soy sauce agroindustry, considering that the business in Cibenda Village, Parigi district, Pangandaran Regency. The data used in this study comes from primary data and secondary data. Primary data comes from direct interviews with soy sauce groindustry owners, where interview are accompanied by a list of questons un the from of questionnaires that have been prepared in advance. Secondary data is data from related institutions. Research results show :1. The costs incurred by the soy sauce agroindustry in one productin processare $R p$ 17.024.435,44, receipts of $R p 21.600 .000$, income earned in the amount of $R p$
\end{abstract}


4.575.564,56, 2. The profitability obtained by the cap soybean agroindustry is $21.18 \%$ in one production process.

Keywords : Agroindustry, soy sauce, Profitability.

\section{PENDAHULUAN}

Pembangunan pertanian dapat didefinisikan sebagai suatu proses perubahan sosial. Implementasinya tidak hanya ditujukan untuk meningkatkan status dan kesejahteraan petanin semata, tetapi sekaligus juga dimaksudkan untuk mengembangkan potensi sumberdaya manusia baik secara ekonomi, sosial, politik, budaya, lingkungan, maupun melalui perbaikan (improvement), pertumbuhan (growth) dan perubahan (change). (Iqbal dan Sudaryanto, 2008)

Salah satu subsistem agribisnis adalah agroindustri, dengan demikian agroindustri kecap merupakan hasil olahan dari gula merah dan kedelai yang banyak digunakan sebagai bumbu dapur dan penyedap makanan berupa cairan berwarna merah kecoklatan yang rasanya manis ataupun asin. Kecap ini selain sebagai bumbu dapur dan penyedap makanan juga memberikan kontribusi yang nyata dalam memenuhi kebutuhan gizi sebagian besar penduduk Indonesia.

Kecap merupakan cairan coklat gelap yang mengandung protein yang dibutuhkan oleh tubuh, kecap dihasilkan melalui hasil fermentasi atau dengan cara kimia (hidrolisis) kacang kedelai. Kecap adalah cairan yang berwarna coklat gelap, dibuat dari fermentasi kacang kedelai yang mempunyai aroma khas dan rasa asin yang biasa ditambahkan sebagai penyedap masakan (Winarno, 1986).

Kecap merupakan pelengkap makanan dan masakan, yang hampir setiap hari dikonsumsi oleh sebagian besar masyarakat di negara kita. Namun, kini kecap semakin populer di dunia, sehingga kecap di produksi secara komersial baik dalam skala komersial, skala industri rumah tangga, ataupun industri besar. Komposisi kimia kecap pada umumnya terdiri atas $69 \%$ protein, $1 \%$ lemak, $9 \%$ karbohidrat, dan 53\% air. Besarnya kadar protein, biasanya digunakan sebagai kriteria penentuan mutu kecap (IKAPI, 2001).

Kualitas kecap ditentukan oleh kadar/kandungan proteinnya. Kadar protein di dalam kecap tergantung pada jumlah unsur $\mathrm{N}$ pada kedelai yang terurai. Jumah $\mathrm{N}$ yang terurai akan semakin tinggi apabila kelapukan kedelai yang dicapai pada saat fermentasi semakin sempurna (IKAPI, 2005). 
Industri kecap cap jago ini merupakan industri yang sudah lama bergerak dalam usaha agroindustri kecap. Usaha ini sudah dirintis pada tahun 1960. Agroindustri kecap cap jago merupakan salah satu agroindustri kecap yang memiliki potensi maju dalam usahanya.

$$
\text { Guna lebih meningkatkan }
$$
keberhasilan pada usaha kecap maka perhitungan biaya dan modal yang digunakan perlu dilakukan dalam setiap proses produksi. Pengalokasian biaya dan modal harus dilaksanakan sebaik-baiknya, untuk mendapat efisiensi penggunaan modal dalam menghasilkan keuntungan. Selain itu nilai profitabilitas merupakan kemampuan perusahaan untuk mendapatkan keuntungan dalam periode tertentu, karena agar dapat melangsungkan hidupnya, suatu perusahaan harus dalam keadaan yang menguntungkan (profitable). Tanpa adanya keuntungan (profit), suatu perusahaan akan sangat sulit untuk menarik modal dari luar. Para kreditur, pemilik perusahaan dan palimg utama dari pihak manajemen perusahaan akan berupaya meningkatkan pendapatan karena sangat disadari sangat penting arti dari profit terhadap kelangsungan dari perusahaan.

Sehubungan dengan latar belakang tersebut, maka penulis tertarik untuk mengadakan penelitian mengenai: "Analisis Profitabilitas Usaha Agroindustri kecap cap Jago" yang merupakan Studi Kasus pada Agroindustri kecap di Desa Cibenda, Kecamatan Parigi, Kabupaten Pangandaran.

\section{METODE PENELITIAN}

Metode penarikan sampel yang digunakan yaitu purposive sampling. Penarikan responden pada penelitian ini secara sengaja (purposive) pada pengusaha agroindustri kecap cap jago yang dianggap paling lama di desa itu, karena sudah berdiri sejak tahun 1960. Metode penelitian yang digunakan dalam penelitian ini adalah metode studi kasus.

Data yang digunakan adalah data primer dan data sekunder. Data primer adalah data yang didapat langsung dari sumber aslinya melalui wawancara, sumber data penelitian yang diperoleh melalui media perantara atau secara tidak langsung yang berupa buku, catatan, bukti yang telah ada, atau arsip yang dipublikasi maupun tidak dipublikasi secara umum.

Data yang diperoleh dianalisis dengan menggunakan metode deskriptif kuantitatif. Menurut Suratiyah (2009), untuk mengetahui besarnya biaya produksi, 
penerimaan, pendapatan, $\mathrm{R} / \mathrm{C}$ dan Profitabilitas adalah sebagai berikut:

1) Analisis Biaya

Untuk menghitung besarnya biaya total (Total Cost) diperoleh dengan cara menjumlahkan biaya tetap (Fixed Cost) dengan biaya variabel (Variable Cost) dengan rumus:

$$
\mathbf{T C}=\mathbf{F C}+\mathrm{VC}
$$

Keterangan:

TC : Total Cost (Biaya Total)

FC : Total Fixed (Biaya Tetap)

VC : Variable Cost (Biaya Variabel)

2) Analisis Penerimaan

Secara umum perhitungan total penerimaan (Total Revenue/TR) adalah perkalian antara jumlah produksi (Y) dengan harga jual (Py) dan dinyatakan dengan rumus sebagai berikut:

\section{$\mathbf{T R}=\mathbf{Y} . \mathbf{P y}$}

Keterangan:

TR : Total Revenue

(Penerimaan Total)

Y: Produksi yang diperoleh

Py : : Harga satuan produk

3) Analisis Pendapatan

Pendapatan adalah selisih antara penerimaan (TR) dan biaya total (TC) dan dinyatakan dengan rumus:

$\mathrm{Pd}=\mathrm{TR}-\mathrm{TC}$

Keterangan:
Pd : Pendapatan.

TR : Total Revenue (Total Penerimaan)

TC : Total Cost (Biaya Total)

4) $\mathrm{R} / \mathrm{C}$

$\mathrm{R} / \mathrm{C}$ adalah perbandingan antara penerimaan dengan biaya total, dinyatakan dengan rumus:

$$
\mathrm{R} / \mathrm{C}=\frac{\text { Penerimaan Total }}{\text { Biaya Total }}
$$

Dengan asumsi:

a. R/C <1, maka usaha tersebut rugi.

b. $\mathrm{R} / \mathrm{C}=1$, maka usaha tersebut tidak untung tidak rugi (impas).

c. R/C >1, maka usaha tersebut untung sehingga layak diusahakan.

5) Profitabilitas

Untuk mengetahui besarnya Proftabilitas menggunakan rumus sebagai berikut :

Net Profit Margin $=\frac{\pi}{\sum \mathrm{TR}} \mathrm{X} 100 \%$

Keterangan:

$\pi$ : Pendapatan (Rp / satu kali proses produksi)

TR : Penerimaan

\section{HASIL DAN PEMBAHASAN}

Data yang digunakan untuk memberikan gambaran umum mengenai identitas perajin meliputi aspek umur, 
pendidikan, pengalaman berusaha dan jumlah tanggungan keluarga.

\section{Umur Perajin}

Umur adalah salah satu faktor yang dapat mempengaruhi seorang dalam bekerja, semakin tua umur seseorang maka kemampuan fisik dalam bekerja semakin berkurang. Umur responden pada penelitian ini yaitu 35 tahun. Anjayani dan Haryanto (2009) menyatakan bahwa penduduk usia produktif adalah yang berumur antara 15 sampai 64 tahun. untuk lebih jelasnya data mengenai umur responden dapat dilihat dalam Lampiran 4.

\section{Tingkat Pendidikan}

Tingkat pendidikan perannya cukup tinggi terhadap seseorang dalam kegiatan suatu usaha, karena tingkat pendidikan dapat mempengaruhi seseorang dalam menerima dan melaksanakan hal-hal yang baru. Tingkat pendidilan formal yang dicapai oleh responden di Desa Cibenda yaitu $\mathrm{S} 1$.

\section{Jumlah Tanggungan Keluarga}

Tanggungan keluarga merupakan salah satu faktor yang sangat erat kaitannya dengan kemampun perajin dalam mengolah usahanya. Semakin banyak jumlah tanggungan keluarga yang harus dipikul oleh seorng perajin akan semakin termotivasi dalam melaksanakan ushanya, dengan harapan pendapatan yang diperoleh akan mencukupi kebutuhan hidup keluarganya.

Tanggungan keluarga pada penelitian ini adalah jumlah anggota keluarga responden yang masih menjadi tanggung jawab responden dalam pemenuhan kebutuhan hidupnya. Berdasarkan hasil penelitian diketahui bahwa jumlah tanggungan keluarga responden yaitu 4 orang. Unit usaha yang dimiliki responden di Desa Cibenda Kecamatan Parigi yaitu satu unit usaha. Responden merupakan generasi ke 3 di perusahaan agroindustri kecap. Pengalaman berusaha merupakan salah satu faktor yang menentukan keberhasilan dalam agroindustri kecap. Semakin lama melakukan proses produksi, yaitu dengan mempelajari pengalaman yang dialami sehingga akan lebih mampu dalam menghadapi kesulitan dan cara penanggulangnanya.

\section{Pengadaan Sarana Produksi}

Pengadaan sarana produksi dalam usaha agroindustri kecap dilakukan oleh perajin, termasuk didalamnya alat-alat yang akan digunakan untuk bahan baku. Penyediaan bahan baku berupa gula merah dan kedelai hitam. Gula merah diperoleh dari daerah Pangandaran dan untuk kedelai hitam didatangkan dari luar daerah Pangandaran. 


\section{Proses Produksi Kecap}

Proses pembuatan kecap cap jago pada dasarnya mencakup langkah-langkah sebagai berikut :

1. Menyiapkan bahan fermentasi kedelai yaitu rebusan air garam yang sudah di fermentasikan.

2. Kemudian menyiapkan bahan selanjutnya yaitu kedelai hitam yang sudah dicuci dan kemudian direbus.

3. Setelah perebusan selesai kedelai dijemur dibawah sinar matahari sampai kadar air yang ada pada kedelai tersebut berkurang, kemudian kedelai difermentasikan dengan rebusan air garam selama 3x24 jam.

4. Tahapan yang selanjutnya kedelai dikeringkan/dijemur dibawah sinar matahari sampai kedelai benar-beanar kering, kemudian fermentasikan kembali dengan campuran rebusan air garam.

5. Proses yang selanjutnya yaitu mengolah gula merah sebanyak 1 ton
(1.000 kg) yang dicampurkan dengan fermentasi kedelai.

6. Proses yang selanjutnya yaitu penyaringan olahan gula merah. Setelah disaring, gula merah diolah kembali dan diberi rempah-rempah untuk menjadikan kecap ini manis dan kental.

7. Proses yang selanjutnya yaitu pendinginan kecap selama 1x24 jam.

8. Selanjutnya kecap yang telah didinginkan selama 1×24 jam tersebut di masukan kedalam botol kaca dengan ukuran $625 \mathrm{ml}$.

9. Setelah botol terisi dengan kecap, beri label kemasan dan segel, kecap cap jago siap untuk didistribusikan.

\section{Analisis Usaha Agroindustri Kecap}

\section{Biaya Tetap}

Biaya tetap yang dihitung dalam penelitian ini meliputi Pajak Bumi dan Bangunan (PBB) serta penyusutan alat yang digunakan untuk kegiatan usaha agroindustri kecap, dan bunga modal per satu kali proses produksi. 
Tabel 1. Analisis Usaha Agroindustri Kecap

\begin{tabular}{|c|c|c|c|c|}
\hline No & Uraian & Jumlah (bulan) & $\begin{array}{l}\text { satu kali } \\
\text { produksi }\end{array}$ & $\begin{array}{c}\text { Persentse } \\
(\%)\end{array}$ \\
\hline \multirow[t]{4}{*}{1} & Biya tetap & & & \\
\hline & PBB & $6,458.00$ & 248.38 & 1.21 \\
\hline & Penyusutan & $520,833.33$ & $20,032.05$ & 97.80 \\
\hline & Bunga modal tetap & $5,272.91$ & 202.80 & 0.99 \\
\hline \multirow[t]{16}{*}{2} & Biaya variabel & & & \\
\hline & Biaya tetap total & $532,564.25$ & $20,483.24$ & 3.85 \\
\hline & Srarana Produksi & & & \\
\hline & 1. Gula Merah Kg & $1,083,333$ & $41,666.67$ & 7.84 \\
\hline & Kedelai Kg & 106,250 & $4,086.54$ & 0.77 \\
\hline & Garam Kg & 12,500 & 480.77 & 0.09 \\
\hline & Botol Kaca Pcs & 78,750 & $3,028.85$ & 0.57 \\
\hline & Transportasi & 8,333 & 320.51 & 0.06 \\
\hline & Listrik w & 3,325 & 127.88 & 0.02 \\
\hline & TutupBotol Pcs & 19,125 & 735.58 & 0.14 \\
\hline & Stiker lembar & 8,325 & 320.19 & 0.06 \\
\hline & Kayu Bakar m³ & 5,000 & 192.31 & 0.04 \\
\hline & Segel Pcs & 1,238 & 47.60 & 0.01 \\
\hline & 11. Penyedap Rasa Kg & 2,083 & 80.13 & 0.02 \\
\hline & 12. Teng kerj & $11,960,000.00$ & $460,000.00$ & 86.54 \\
\hline & Biaya Varibel Total & $13,288,263$ & $511,087.02$ & 96.15 \\
\hline 3 & Biaya Total & $13,820,826.75$ & $531,570.26$ & 100.00 \\
\hline
\end{tabular}

Tabel 1 menunjukkan bahwa besarnya biaya total Rp. 17.024.435,44 yang terdiri dari biaya variabel sebesar Rp. 16.455.000 dan total biaya tetap sebesar $\mathrm{Rp}$.
$569.435,44$, biaya terbesar adalah biaya untuk pembelian gula merah yakni sebesar Rp.13.000.000.

Tabel 2. Analisis Penerimaan Agroindustri Kecap Penerimaan Hasil Agroindustri Kecap di Desa Cibenda Untuk Satukali Proses Produksi

\begin{tabular}{clr}
\hline No & \multicolumn{1}{c}{ Uraian } & Jumlah \\
\hline 1 & Total Produksi Kecap (botol) & 1.350 \\
2 & Harga Produk (Rp/botol) & 16.000 \\
3 & Total Penerimaan (Rp) & 21.600 .000 \\
\hline
\end{tabular}

Tabel 2 menunjukkan bahwa produksi kecap adalah 1.350 botol, sedangkan harga kecap pada saat penelitian
Rp. 16.000 per botol, maka penerimaan agroindustri kecap dalam satu kali proses 
produksi di Desa Cibenda sebesar Rp.

21.600 .000

Tabel 3. Penerimaan, Pendapatan dan R/C Agroindustri Kecap dalam Satu Kali Proses Produksi.

\begin{tabular}{clrr}
\hline No & \multicolumn{1}{c}{ Uraian } & Jumlah (bulan) & \multicolumn{1}{c}{ satu kali produksi } \\
\hline 1 & Biya Varibel Total & $13,288,263$ & $511,087.02$ \\
2 & Biya Total & $13,820,826.75$ & $531,570.26$ \\
3 & Produksi & $1,350.00$ & 51.92 \\
4 & Harga & 16000 & $16,000.00$ \\
5 & Penerimaan & 21.600 .000 & $830,769.23$ \\
6 & Pendapatan & $7,779,173.25$ & $299,198.97$ \\
7 & R/C & 1.56 & 1.56 \\
\hline
\end{tabular}

Tabel 3 menunjukkan bahwa total biaya produksi yang dikeluarkan sebesar Rp 13,820,826.75, penerimaan sebesar Rp. 21.600.000,00, sehingga pendapatan yang diperoleh agroindustri kecap di Desa Cibenda sebesar $\mathrm{Rp} 7,779,173.25$, dalam satu kali proses produksi.

\section{Profitabilitas Usaha Agroindustri Kecap}

Profitabilitas digunakan untuk melihat kemampuan agroindustri kecap dalam periode tertentu, dihitung dalam satu kali proses produksi. Berdasarkan hasil perhitungan diketahui bahwa biaya total yang dikeluarkan per satu kali proses produksi Rp 13,820,826.75, penerimaan sebesar Rp 21.600.000, pendapatan yang diperoleh dari hasil usaha agroindustri kecap per satu kali proses produksi adalah sebesar $\mathrm{Rp} 7,779,173.25$, maka dengan demikian dapat dihitung nilai profitabilitasnya sebagai berikut :

- Net Profit Margin $=\frac{\pi}{\mathrm{TR}} \times 100 \%$

$$
\begin{aligned}
\text { Net Profit Margin } & =\frac{7,779,173.25}{21.600 .000} \times 100 \% \\
& =36,01 \%
\end{aligned}
$$

- Gross Provit Margin $=\frac{\mathrm{TC}}{\mathrm{TR}} \mathrm{X} 100 \%$

$$
\begin{aligned}
& =\frac{13,820,826.75}{21.600 .000} \times 100 \% \\
& =63.98 \%
\end{aligned}
$$

Hasil perhitungan menunjukan bahwa Net Provit Margin nya adalah sebesar 36,01 \% artinya kemampuan perusahaan untuk menghasilkan laba yaitu 36,01 \% dan Gross Profit Margin nya adalah sebesar $63.98 \%$ dari jumlah modal yang dikeluarkan sebesar Rp 21.600.000. 


\section{KESIMPULAN DAN SARAN}

\section{Kesimpulan}

Berdasarkan hasil penelitian dan pembahasan dapat diambil kesimpulan sebagai berikut :

1. Besarnya biaya produksi yang dikeluarkan oleh agroindustri kecap cap jago adalah Rp 13,820,826.75, besarnya penerimaan yang diperoleh kecap adalah $\operatorname{Rp} 21.600 .000$, dan besarnya pendapatan yang diperoleh Rp 7,779,173.25

2. Besarnya nilai $\mathrm{R} / \mathrm{C}$ sebesar 1.56 dalam satu kali proses produksi.

3. Besarnya nilai profitabilitas laba bersih (Net Profit Margin) perusahaan kecap cap jago adalah sebesar 36,01\% dan nilai Laba kotor (Gros Profit Margin) adalah sebesar $63,98 \%$

\section{Saran}

Disarankan bagi perusahaan untuk lebih meminimalisir biaya, dari segi bahan baku, dan pembelian bahan baku yang banyak agar mendapatkan harga yang lebih murah. Dan agar memperluas lagi pendistribusian kecap cap jago.

\section{DAFTAR PUSTAKA}

Anjayani dan Haryanto. 2009. Geografi : jelajah Bumi dan alam Semesta. Citra Raya. Bandung.

Iqbal, M. Dan T. Sudaryanto. 2008. Tanggung Jawab Sosil Perusahaan (Corporate Social Responsibility) Dalam Prespektif Kebijakan Pembangunan Pertanian. Periode 11-13 Oktober 2008). Universitas Sebelas Maret.

IKAPI (2001). Membuat Kecap : Tempe Busuk : Nira, Air kelapa. Yogyakarta Penerbit Kanisius. Hal 13

(2005). Kecap Tradisional. Yogyakarta. Penerbit Kaninus. Hal 42

Suratiyah. 2009. Ilmu Usahatani. Penebar Swadaya. Jakarta.

Winarno, F.G. 1989. Kimia Pangan dan Gizi. Jakarta. Gramedia Pustaka Utama. 